\title{
Problems of Development of Small and Medium Enterprise (SME) in Russia and Methods of Solving Them
}

\author{
Olga Chemodanova \\ Department of Management \\ Finance University under the Government of the Russian \\ Federation \\ Moscow, Russia \\ ochemodanova@fa.ru
}

\begin{abstract}
The problems of the SME sector development in our country are really topical at present. The role of SMEs in the Russian economy has significantly increased in the conditions of the 2014-2015 economic crises and the difficult geopolitical situation of our country in the world arena. Small and medium-sized enterprises have a number of advantages that contribute to the development of domestic and foreign trade.
\end{abstract}

Keywords-small and medium-sized enterprise; economic crisis; administrative barriers; tax burden; public organization for small and medium-sized enterprises; individual entrepreneurs; RSBI

\section{INTRODUCTION}

The specific features of small and medium-sized businesses functioning should be studied in relation to a certain period, because the defining feature of these businesses is a rapid response to environmental changes in economic, social and political spheres. At the present period, the sphere of SMEs has undergone significant changes being influenced by the economic crisis of 2014 in Russia, the imposition of sanctions due to the complex political situation with the United States and European Union countries, and consequently, by the reduction of foreign investments. The economic crisis contributed to reduction in the number of small and medium-sized enterprises which terminated their activities or switched to the "shadow" economy illegal sector. This fact indicates a reduction in the number of workplaces and outflow of investments from the SME sector, which affects the development and functioning of the national economy on the whole.

\section{General Problems of SME Sector AND A NeW STATE SUPPORT POLICY FOR SME}

There exist a number of problems that especially influence the development of small and medium-sized business in Russia [1]. First, SMEs are highly dependent on changes in the external environment, which include many

\author{
Gleb Grib \\ Government Administration and Financial Control \\ Department \\ Finance University under the Government of the Russian \\ Federation \\ Moscow, Russia \\ BFF231@yandex.ru
}

factors slowing down the development of SMEs. These factors can be detailed in five groups, which are reported in "Table I".

TABLE I. GENERAL PROBLEM GROUPS OF SMES

\begin{tabular}{|l|l|}
\hline Problem group & \multicolumn{1}{|c|}{ Description } \\
\hline Organizational & $\begin{array}{l}\text { Legal registration, the process of opening of a } \\
\text { bank account, administrative barriers }\end{array}$ \\
\hline $\begin{array}{l}\text { Material and } \\
\text { technical support }\end{array}$ & $\begin{array}{l}\text { Deficiency of fixed assets (buildings and } \\
\text { equipment), insufficient qualification of } \\
\text { employees, low level of legal security }\end{array}$ \\
\hline $\begin{array}{l}\text { Financial } \\
\text { (investment) }\end{array}$ & $\begin{array}{l}\text { Problems with individual savings capitalization } \\
\text { and formation of start-up capital, difficulties at } \\
\text { legalizing capital when registering an enterprise, } \\
\text { difficulties in arranging contacts with suppliers, } \\
\text { tax burden }\end{array}$ \\
\hline Credit insecurity & $\begin{array}{l}\text { Lack of cash to open an enterprise; problems in } \\
\text { obtaining a loan, high interest rate }\end{array}$ \\
\hline $\begin{array}{l}\text { External } \\
\text { environment and } \\
\text { market conditions }\end{array}$ & $\begin{array}{l}\text { Unfavorable environment, insufficient adaptation } \\
\text { to a dynamically developing market, geopolitical } \\
\text { risks, systemic risks }\end{array}$ \\
\hline
\end{tabular}

In their business activity, the SME sector focuses on consumer demand; and with a view to the Crisis, there is a significant inflation and a decrease in purchasing power of currency. In its turn, this sector of the business reduces the scale of its business, which helps in hiding incomes and minimizing the tax burden [2]. As a result, problems in the sphere of SMEs demonstrate a contagion effect, i.e. each new problem appears after the previous one. "Table II" presents the problem points, considering the categories of SME entrepreneurship in the Russian economy at the present stage. 
TABLE II. SPECIFICS OF SME IN RUSSIA AFTER THE 2014 ECONOMIC CRISIS.

\begin{tabular}{|c|c|}
\hline $\begin{array}{c}\text { Category of small and medium- } \\
\text { sized enterprises (SME) }\end{array}$ & Features and functioning problems \\
\hline $\begin{array}{l}\text { Subjects of SME actively using } \\
\text { loaned funds for the production } \\
\text { of goods and services }\end{array}$ & $\begin{array}{l}\text { A small volume of bank financing, } \\
\text { revaluation of collateralized property, } \\
\text { shortage of current capital, } \\
\text { deterioration in credit facility, } \\
\text { transition to illegal activities } \\
\begin{array}{l}\text { contributing to the shadow } \\
\text { economy[3] }\end{array}\end{array}$ \\
\hline $\begin{array}{l}\text { Subjects of SME manufacturing } \\
\text { products or goods for medium } \\
\text { and large businesses }\end{array}$ & $\begin{array}{l}\text { Reduced demand on SME goods, risk } \\
\text { of counterparties' non-payment }\end{array}$ \\
\hline $\begin{array}{l}\text { Subjects of SME that provide } \\
\text { support services (marketing, } \\
\text { personnel servants, small-scale } \\
\text { production, advisory and } \\
\text { information) }\end{array}$ & $\begin{array}{l}\text { Reduced demand on these services, } \\
\text { non-payment risk }\end{array}$ \\
\hline $\begin{array}{l}\text { Subjects of SME operating in the } \\
\text { construction sphere and support } \\
\text { services provision (production of } \\
\text { materials, construction and repair } \\
\text { works) }\end{array}$ & $\begin{array}{l}\text { Reduced demand on these services } \\
\text { and products, cost reduction }\end{array}$ \\
\hline $\begin{array}{l}\text { Subjects of SME engaged in } \\
\text { wholesale and retail trade }\end{array}$ & $\begin{array}{l}\text { Growing the cost of imported } \\
\text { products, current capital shortage } \\
\text { which in med-term perspective leads } \\
\text { to demand reduction on these products }\end{array}$ \\
\hline $\begin{array}{l}\text { Subjects of SME operating in } \\
\text { restaurant business and fast food } \\
\text { sector }\end{array}$ & $\begin{array}{l}\text { Reduced demand on these services } \\
\text { and products, economic slowdown } \\
\text { (profitability, liquidity) }\end{array}$ \\
\hline $\begin{array}{l}\text { Subjects of SME operating in the } \\
\text { transport sector }\end{array}$ & $\begin{array}{l}\text { Reduced demand on these services } \\
\text { and products, economic slowdown } \\
\text { (profitability, liquidity) }\end{array}$ \\
\hline $\begin{array}{l}\text { Subjects of SME working for } \\
\text { state and municipal orders }\end{array}$ & $\begin{array}{l}\text { Contest for municipal and state } \\
\text { orders, increased competition, } \\
\text { negative factors }\end{array}$ \\
\hline $\begin{array}{l}\text { Subjects of SME working on } \\
\text { investment projects aimed at } \\
\text { modernization and production } \\
\text { expansion }\end{array}$ & $\begin{array}{l}\text { "Projects freezing", funds shortage for } \\
\text { implementation of new projects }\end{array}$ \\
\hline All subjects of SME & $\begin{array}{l}\text { Administrative barriers, inspections, } \\
\text { reduction of capital turnover, } \\
\text { reduction in wage workers' number }\end{array}$ \\
\hline
\end{tabular}

From this table it can be concluded that most functioning problems and features depend on the field of activity where SME operate.

The President of the Russian Federation Vladimir Vladimirovich Putin expressed his opinion in support of entrepreneurship: "I consider freedom of entrepreneurship to be the most important economic and socially significant issue. The expansion of this freedom of entrepreneurship will be our respond to all the restrictions they try to create for us. That is why we have allowed such wide latitude to the newly created Federal Corporation for the Development of Small and Medium-sized Businesses. Ministries and departments, governors, heads of all regions of the Russian Federation, state companies and banks are requested to provide this body with all necessary assistance"(03.12.2015) [4].

The main characteristics of the positioning of the new SME state support policy are:

\section{A. Acceleration System for SME}

Acceleration system for small and medium-sized businesses forms a number of privileges, which include tax and property benefits. However, there is a tendency to support already functioning SME on a certain level. The expansion of business activities is not profitable for entrepreneurs, as a rule, because this significantly increases administrative or fiscal burdens imposed on them.

Expansion should be understood as an increase in the volume of production or in the number of employees. For instance, a small excess of special tax regimes threshold values obliges entrepreneurs to switch to the usual system of taxpaying. It can be concluded that enterprises do not want to move to a new level of development and expand, as this will result in increase of fiscal burden. Acceleration of growth should work as an encouragement for start-up entrepreneurs for entrepreneurial activities and for small businesses - for their expansion to a medium level. With this view, the given model should include a various approaches that will help entrepreneurs realize their potential from a financial point of view, primarily by means of reducing the tax burden.

\section{B. Feedback Improvement and Monitoring of Business Decisions in Business Regulation Sphere}

In the period of 2013-2014, the monitoring of the results of SME sector support policies was effectively implemented. First of all, one must note the effectiveness of the road maps of the National Entrepreneurship Initiative aimed at improving the development of various business areas (from the customs and administrative burden to valuation activities and the expansion of SME access to state and exclusive purchasing).

To the order of the Government of the Russian Federation No. 1613-r dated September 6, 2012, the Agency for Strategic Initiatives (ASI), together with associations of entrepreneurs, exporters and executive branch members, regularly analyze the effectiveness of road maps.

\section{Advocacy of Entrepreneurship [5]}

The analytical study "Amway Global Entrepreneurship Report 2014" and the Levada Center survey on "Russians about business and businessmen" demonstrated that a large percentage of respondents $(75 \%)$ expressed their positive attitude towards the activities of entrepreneurs. However, the percentage of emergent entrepreneurs among the able-bodied population in our country is extremely small: it constituted $5.8 \%$ in 2014. For comparison, in USA this index is $12.7 \%$, in China-14.0\%, in Brazil-17.3\%, in India-9.9\%, in South Africa-10.6\%. However, Russia is ahead of Italy, France and Germany in this index.

An important state task is the involvement of citizens in entrepreneurial activities, since it is the representatives of the federal level who set trends for the development of economy and society as a whole. 


\section{Promotion of Youth Entrepreneurship [6]}

An important national task is the preparation of younger generation, of educated, competent and successful young businessmen. Beginning with 2009, the program "You are an entrepreneur" is being implemented. This program helps young people in developing certain skills and abilities that will help them in their future work on their own businesses. Since that time, more than 700,000 young people from 68 Russian regions have been involved in this program, about 10000 enterprises have been opened. It is worth highlighting the program "You are an entrepreneur" as a separate state program, giving it economic and social significance, with due financing from the state budget; and special educational programs for schools and universities should be developed, that solve the personnel problem in business.

\section{E. Replicating Examples of Best Practices of the National Business Activity [7]}

Spotting of the best entrepreneurial practices of SME is an urgent task in supporting business at the municipal level. At the municipal level, a range of programs is being developed to promote entrepreneurship and improve the investment climate. However, this does not always work in an effective way. To motivate the work of local governments in this area, it is necessary to establish a good relationship with the business community and the All-Russian Public Organization for Small and Medium-Sized Enterprises «OPORA ROSSII». The all-Russian public organization "Delovaya Rossiya" has developed the "Atlas of municipal practices", which is a compendium of successful entrepreneurship practices and outlines directions for the development and support of SMEs at the municipal level. In the preparation of the Atlas, the experience of 65 municipal entities in 35 regions of the Russian Federation was used, which, as of 2015, showed high rates of investment activity development.

Thus, the suggested measures of supporting and developing SME will help in solving the main problems in the sphere of small and medium-sized business in Russia.

\section{Statistics AND INDiCES OF SMALL AND MEDIUM ENTREPRENEURSHIP}

The analysis of the SME segment sectoral structure shows that with the growth of the company's size, its specialization changes in favor of more complex and largescale activities.

Individual entrepreneurs, micro enterprises and small enterprises concentrated their activities mainly in the spheres of service rendering and trade. As for medium-sized enterprises, they focus on manufacturing, construction and agriculture, i.e., on high-added value sectors. Most of medium-sized enterprises are engaged in reproductive and innovative activities under an effective management system. It is this segment that exercises a qualitative breakthrough in the economy, improving the business environment for new micro and small enterprises, providing them with market channels for goods and services [8].

Thus, about $36 \%$ of small and medium-sized entrepreneurs are engaged in trading business. A rather significant share $-30.1 \%$ - is engaged in the service sector. The share of enterprises engaged in production amounts to $17.1 \%$, in construction - to $11.6 \%$. The least represented in the segment of SME happened to be agricultural companies $5.7 \%$ of the total number of enterprises, as shown in "Fig. 1".

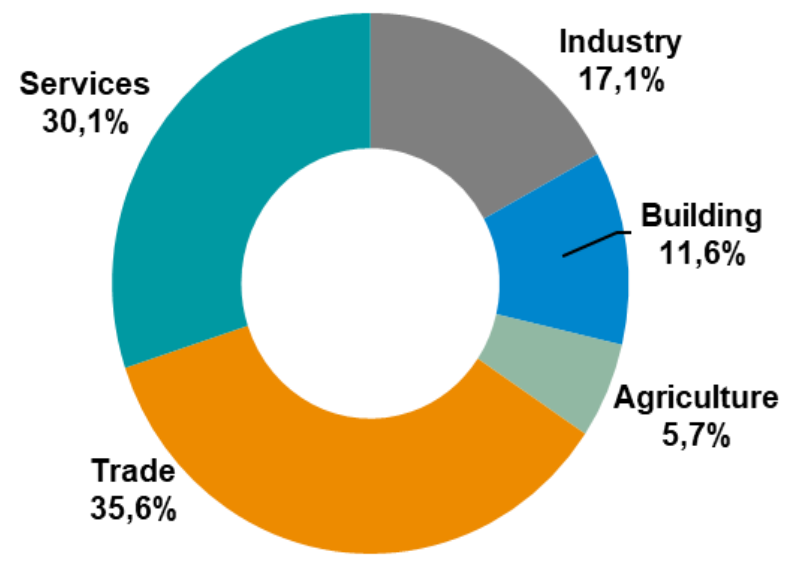

Fig. 1. Sectoral structure of SME entities for 2015.

The development of small and medium-sized businesses in Russia occurs on an uneven basis. The concentration of SME is typical of only certain regions. According to statistical studies, 10 subjects of Russia with the largest number of small and medium-sized businesses account for $46 \%$ of the total amount of SME in the country. As for individual entrepreneurs, their rate is $37 \%$ of the total for 10 regions. On this basis, it can be concluded that the dynamics and growth of SME in Russia overwhelmingly depends on the state of small and medium-sized business in leading regions.

Analyzing the SME business activity with consideration of the RSBI-index (Russia Small Business Index) - an indicator that assesses business activity in the SME segment, one can clearly see the dynamics in its component in 20142016 as in "Table III". 
TABLE III. DYNAMICS OF THE MAIN COMPONENTS OF THE RSBIINDEX

\begin{tabular}{|cccccc|}
\hline \multicolumn{5}{|c|}{ Dynamics of the main components of the RSBI-index } \\
Period & RSBI & Sales & Staff & $\begin{array}{c}\text { Availability } \\
\text { of financing }\end{array}$ & $\begin{array}{c}\text { Willingness } \\
\text { to invest }\end{array}$ \\
3Q. 2014 & 46 & 49,0 & 54,2 & 43,3 & 38,8 \\
\hline 4Q. 2014 & 39,8 & 36,5 & 51,0 & 38,8 & 35,9 \\
1Q. 2015 & 41,4 & 40,7 & 50,2 & 36,8 & 39,8 \\
2Q. 2015 & 44,6 & 48,1 & 52,0 & 38,2 & 40,9 \\
3Q. 2015 & 42,8 & 43,5 & 49,7 & 41,4 & 37,7 \\
4Q. 2015 & 38,2 & 33,0 & 49,9 & 41,0 & 32,3 \\
1Q. 2016 & 42,3 & 44,5 & 50,6 & 41,8 & 33,6 \\
\hline
\end{tabular}

All sectoral components of the RSBI in 1st quarter of 2016 reflected the growth of business activity. The indicator in production looks better than other segments, while the indicator in the service sector looks worse. In the aspect of business enterprises' size, the downturn in business activity has also slowed down. Here the average business looks better and the weakest is micro-business [9]. Among the additional components of RSBI, as a positive dimension, we mark an end to the outflow of buyers / customers from entrepreneurs and a slowdown in the deterioration of general conditions for doing business. At the same time, sales prices accelerated their growth, while the prime cost increase has slowed down.

The message of the President of the Russian Federation Vladimir Putin dated December 4, 2014, addressed to the Federal Assembly, formulated a new state policy aimed at supporting SME. The Message runs: "Conscientious work, private property, freedom of entrepreneurship are the same basic conservative values as patriotism, respect for history, traditions and culture of your native country. We all want one same thing - the welfare of Russia. And the relations between business and the state should be built on the philosophy of the common cause, on partnership and equal dialogue" [10].

The new state policy in support of the SME sphere is based on the following rules:

- Small business carries in itself not only an economic but also a social function. This is marked especially strongly in settlements with a small population and a low economic level;

- The potential for entrepreneurial activity will be realized only if fiscal and regulatory authorities are stable and guaranteed, and in the event that the authorities are interested in the success of the SME sector;

- The future of the national economy depends on the economic activity of young people, who should try and develop their settlements (regions, cities, villages).

\section{CONClusion}

In the GDP of Russia, small and medium businesses make up a part of $20-21 \%$. This index is much smaller than that of developed countries, where the SME sector produces on average up to $50 \%$ of the gross domestic product.

At the moment, there are a number of the problems for small and medium-sized enterprises in Russia. Among them, one can single out a high level of taxes, unfavorable environment, low adaptation to a dynamically developing market, administrative barriers, geopolitical risks, systemic risks, legal and financial illiteracy of resident entrepreneurs, as well as the financial resources and start-up capital shortage. All these problems require a qualitative systematization and a structural approach to their solution. The state actively promotes the policy of supporting the SME segment. Innovative projects have been developed, within which entrepreneurial activities in our country will be developed and encouraged by providing various benefits and financing to start-up entrepreneurs.

\section{REFERENCES}

[1] Entrepreneurship in Russia: theory, problems, prospects. Collective monograph, Yu. A. Romanova (ed.). M.: Publishing House "Scientific Consultant", Financial University under the Government of the Russian Federation, 2017, p. 262.

[2] A.O. Blinov, O.S. Rudakova, Instruments of government support of innovative small entrepreneurship in the countries of market economy", Naukograd, science, production, society. 2014, No 2, pp. 31-39.

[3] Hmelnitchi //Quality Management System an ace in the sleeve of the SME to gain competitiveness on the international markets .Carmen \& Neamtu, 2013.- Access code: http://mybrary.ru

[4] Message of the President of the Russian Federation to the Federal Assembly dated 04.12.2014

[5] G.Yu. Grib, O.N. Chemodanova, The main institutional problems of the development of small and medium-sized businesses in Russia and ways to solve them. Economics and management: problems, solutions. M.: 2016, No. 3, vol. 1 (51), pp. 22-26.

[6] E. Yu. Savicheva, Evaluation of the state and prospects for the development of small innovative business in Russia. Journal of Creative Economy, 2014, No. 9 (93), pp. 43-53.

[7] A. O. Blinov, O.S. Rudakova, Difficulties and contradictions of development of small business in Russia. Kazan social and humanitarian bulletin, 2013, No. 1 (7), pp. 3-8.

[8] N. S. Afanasyeva, O. N. Chemodanova, Management of competitiveness of enterprises in the sphere of financial and banking services in crisis conditions. Economics and management: problems, solutions. M.: 2015, No. 9, pp. 173-177.

[9] http://www.consultant.ru/ SPS Consultant Plus (circulation date: 05 September, 2017)

[10] http://rsbindex.com/ - Index of RSBI Support, study of business sentiments of small and medium businesses (circulation date: 05.09.2016) 